\title{
TREND ASSESSING USING MANN-KENDALL'S TEST FOR PRIŠTINA METEOROLOGICAL STATION TEMPERATURE AND PRECIPITATION DATA, KOSOVO AND METOHIJA, SERBIA
}

\author{
NIKOLA R. BAČEVIĆ ${ }^{1 *}$, MILICA PAVLOVIĆ ${ }^{1}$, ILHANA RASLJANIN ${ }^{1}$ \\ ${ }^{1}$ Faculty of Natural Sciences and Mathematics, University of Priština, Kosovska Mitrovica, Serbia.
}

\begin{abstract}
The study includes statistical analysis of Priština meteorological station data on temperature and precipitation trends. The data are organized into four time series: average annual air temperatures (Ta), average maximal annual air temperatures (Tamax), average minimal annual air temperatures (Tamin), as well as annual precipitation sums (RRsum), all in the period 1949 - 1999. The Mann-Kendall's (MK) trend test analysis of the corresponding hypotheses discloses that the $H_{0}$ hypothesis should be accepted. The general conclusion is that there is no trend neither in maximal, minimal, average temperatures, nor in average annual precipitation for the 1949 - 1999 period for the central Kosovo and Metohija (K\&M).
\end{abstract}

Keywords: Air temperature trend, Mann-Kendall, Precipitation trend, Priština, Kosovo and Metohija, Serbia.

\section{INTRODUCTION}

According to the Intergovernmental Panel on Climate Change (IPCC 2007) report, the global average temperature have risen for $0.7^{\circ} \mathrm{C}$ within the last 100 years. However, the global temperature rise is not distributed uniformly over the all of the Earth surface.

The rise varies in different regions. Using data from 168 meteorological stations across European continent, Klein Tank (2002) presented tendency of the European average temperature rise. In general, an average temperature rise in Europe is recorded both on annual and seasonal levels (Brázdil et al., 1996; Brunetti, 2004; Feidas, 2004; Brunet, 2007).

In Serbia a trend of average temperature rise after 1975 is recorded too (Unkašević \& Tošić, 2011). The results analysis of data on temperature extremes from 15 meteorological stations for the period 1949 - 2009 reveal that the climate in Serbia shows a worming tendency within last 61 years (Unkašević \& Tošić, 2013). Similar results on climate in our country were published recently (Ducić \& Radovanović, 2005; Unkašević \& Tošić, 2009; Gavrilov et al., 2010, 2013a; Tošić et al., 2013; Hrnjak et al., 2013; Vukoičić et al., 2018; Milentijević et al., 2018). The climate in K\&M was subject of several studies (Gavrilov et al., 2018; Ivanović et al., 2017; Bačević et al., 2017) and shows a mild temperature rise tendency for the 1949 - 1999 period. GIS analysis in combination with numerical methods are very powerful tool for calculating and climatological properties (Valjarević et al., 2018).

The focus of the study is the average annual and seasonal temperature and precipitation rise in Priština (central K\&M) region for the 1949 - 1999 period.

\section{MATERIAL AND METHODS}

Data

The data from Priština meteorological station were organized into four time series: the average annual air temperatures $(\mathrm{Ta})$, average maximal annual air temperatures (Tamax), average minimal annual air temperatures (Tamin), and annual precipitation sum (RRsum), all of them for the 1949 1999 period. While forming the time series, we noticed that the data for some of the years were incomplete. Therefore, the completion of the data was needed in order to form the time series (Douglas et al., 2000). For that reason Random number generator function was done for the missing data. As a result, we obtained comprehensive time series, and could start with the data processing using Microsoft Office Excel 2007. One column was used to input data for the 1949 - 1999 period, and another to input the time series. Both columns are marked and, using Scatter function, a graph showing the temperature values is obtained. The graph was transformed into 2-D histograms more convenient for the time series analysis. The resulting histogram consisted of 51 bars, the $x$ axis was used to represent years, and the $y$ axis was used to represent the measured values. In order to create the trend curve, a special function should be activated in Excel 2007. In the Trendline options check-box we check the linear trend function. The Display Equation on Chart option helps us in obtaining the formula. Here one can arrange the trend line, color, size and the value units. In this way we formed four graphs (figure 1 - the annual precipitation sum distribution, figure 2 - the average maximal annual temperatures, figure 3 the average minimal annual temperatures, figure $4-$ the average annual temperatures. 
Trend

The temperature and precipitation trends were examined using three statistical analyses. The first data processing was used to calculate linear equations representing Priština meteorological station data trends. The trend was represented with a linear curve showing values of annual (maximal, minimal, average) temperatures and annual precipitation sums. The second statistical processing was done using XL-stat software that uses MK test on temperature and precipitation (Gilbert, 1987). The test is mostly used in environmental sciences that require meteorological data processing (e.g. Gavrilov et al., 2010, 2011, 2013a, 2018; Hrnjak et al., 2013). The MK trend test is very convenient because it could be used for different groups of data (Kendall, 1938, 1975). The minimal number of time series for a successful test is ten. After the trend processing, the XL-stat software tests two hypotheses: (1) $H_{a}$ - there is a trend, and (2)
$H_{0}-$ there is no trend in time series. The trend probability is defined through the scientific reliability level $(\alpha-0.05)$. In the third data processing, differences between the first and the last values of temperatures/precipitation were calculated for the 1949 - 1999 period. These values represent the quantitative measure/value $(\Delta y)$.

\section{Study area}

Priština, the capital of K\&M province is located in the north part of Kosovo basin, on foothills of the Grmija Mountain. The urban core area covers $857 \mathrm{~km}^{2}$, its altitude is $652 \mathrm{~m}$ above the sea level, and coordinates are: latitude $42^{\circ} 65^{\prime} \mathrm{N}$ and longitude $21^{\circ} 15^{\prime}$ E. Priština meteorological station is located near the city airport, in Goleš. Its coordinates are: latitude $42^{\circ} 67^{\prime} \mathrm{N}$ and longitude $21^{\circ} 17^{\prime} \mathrm{E}$, and its altitude is $573 \mathrm{~m}$ (Gavrilov et al., 2018)

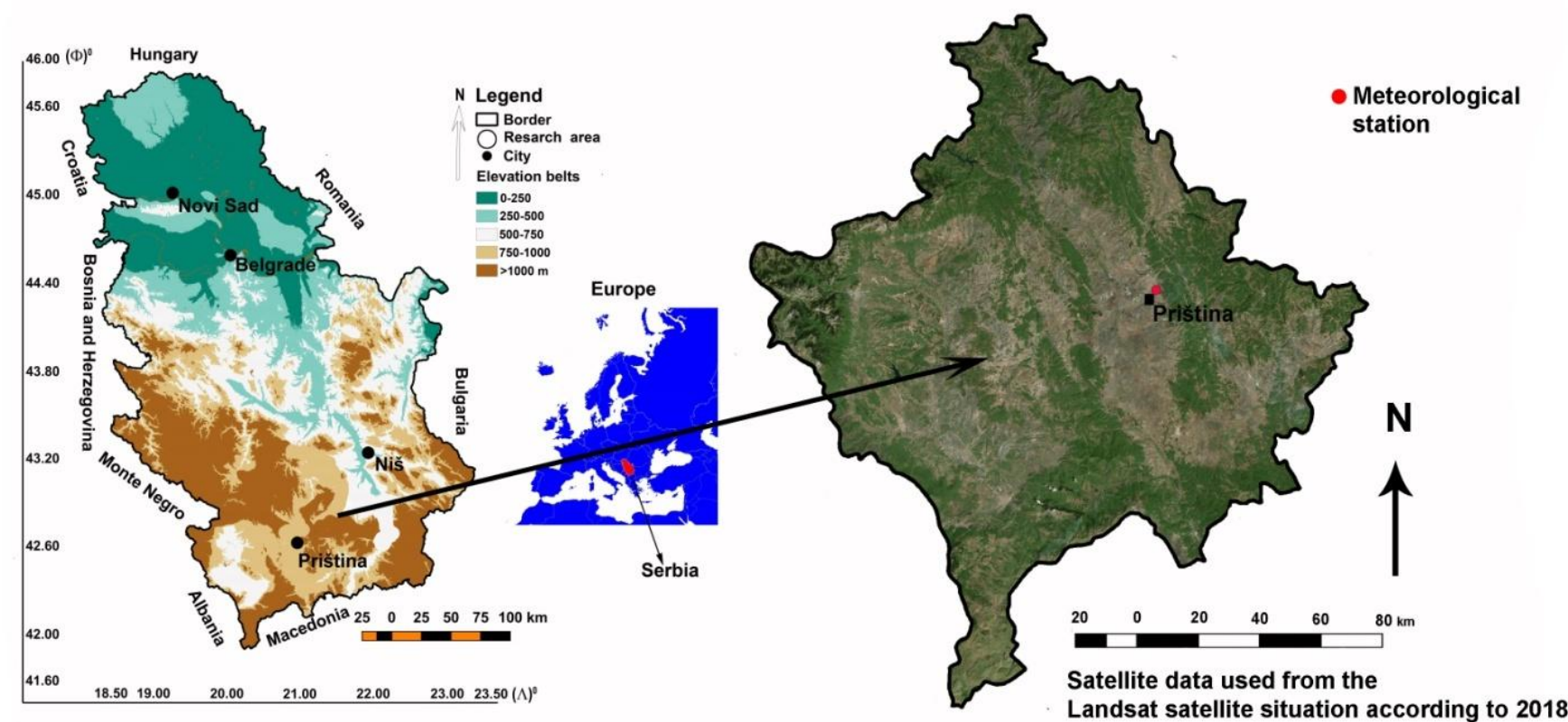

Figure 1. Physical-geographical map of the Republic of Serbia and Kosovo and Metohia in Europe, and the position of the meteorological station of Prishtina, which is especially marked with red circles.

\section{NUMERICAL RESULTS}

The four time series were subjected to three different ways of statistical data processing. The corresponding equations and relevant values for precipitation, maximal, minimal and average temperatures are as follows:

$$
\begin{aligned}
& (1-\text { RRsum })_{1,2,3,4} \\
& y=-0.645 x+597.8, \tau=-0.073, p=0.457, \Delta y_{p}=39.96 . \\
& (2-\operatorname{Ta} \max )_{1,2,3,4} \\
& y=0.013 x+23.1, \tau=0.104, p=0.292, \Delta y=-0.65
\end{aligned}
$$

$$
\begin{aligned}
& (3-T a \min )_{1,2,3,4} . \\
& y=0.011 x-2.9, \tau=0.137, p=0.162, \Delta y=-0.58 . \\
& (4-T a)_{1,2,3,4 .} \\
& y=-0.005 x+10.2, \tau=-0.073, p=0.471, \Delta y=0.25 .
\end{aligned}
$$

The first equation (1-Rrsum) $)_{1,2,3,4}$ represents the average precipitation sum in Priština for the 1949 - 1999 period, 1 - the linear equation, 2 - Kendall $\tau$ value (the range of values from + 1 to -1$), 3-p$ - the trend probability, $4-\Delta \mathrm{y}_{\mathrm{p}}$ is the difference in values at the beginning and the end of the period. The second equation $(2-T a \max )_{1,2,3,4}$ represents average maximal annual 
temperatures in Priština for the 1949 - 1999 period, 1 - the linear equation, 2 - Kendall $\tau$ value (the range of values from +1 to 1), $3-p$ - the trend probability, $4-\Delta \mathrm{y}_{\mathrm{p}}$ is the difference in values at the beginning and the end of the period. The third equation (Tamin) $)_{1,2,3,4}$ represents average minimal annual temperatures in Priština for the 1949 - 1999 period, 1 - the linear equation, 2 - Kendall $\tau$ value (the range of values from +1 to 1), $3-p-$ the trend probability, $4-\Delta \mathrm{y}_{\mathrm{p}}$ is the difference in values at the beginning and the end of the period. The fourth equation $(\mathrm{Ta})_{1,2,3,4}$ represents average annual temperatures in Priština for the 1949 - 1999 period, 1 - the linear equation, 2 Kendall $\tau$ value (the range of values from +1 to -1 ), $3-p-$ the trend probability, $4-\Delta y_{p}$ is the difference in values at the beginning and the end of the period.
All four trends with their linear equations and magnitudes were obtained with the XL-stat software. There we dealt with (maximal, minimal, average) temperatures, as well as with precipitation sums. The conclusion is that the $H_{0}$ hypothesis should be accepted. It shows that there is no trend in the time series. Besides, in equations $(1,2,3,4)$ we calculated the Kendall $\tau$ correlation value, $p$ value and the trend magnitude value $(\Delta y)$

Figures (2), (3), (4), (5) represent results of trend testing with the MK test with respective hypothesis assessment. Using these results we analyze trends for four time series.

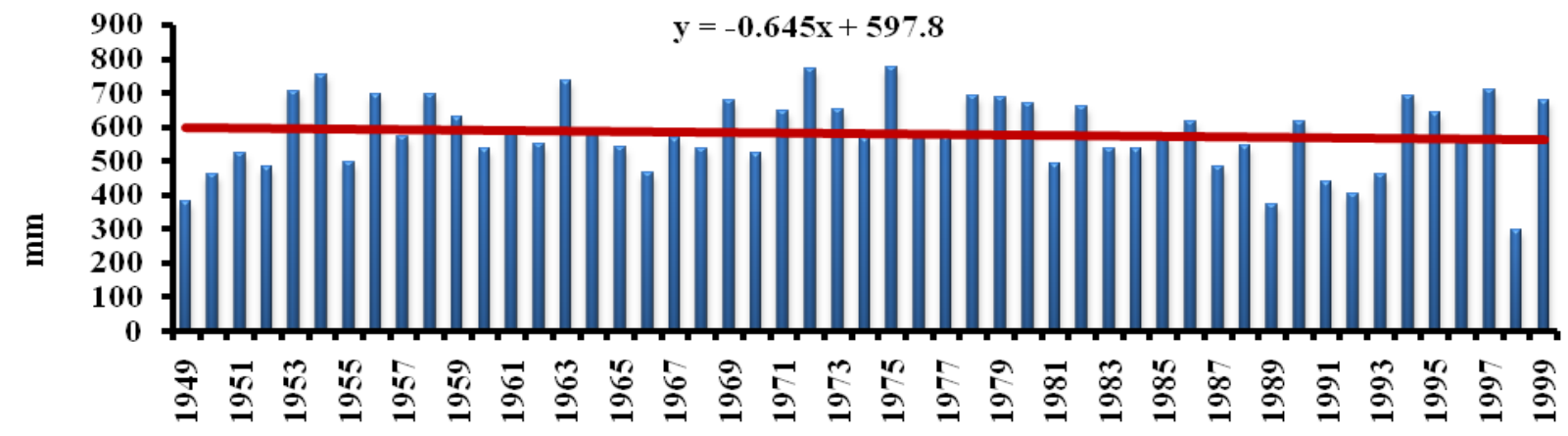

Years

Figure 2. Annual precipitation sum distribution, the trend line and the trend equation for Priština in the 1949 - 1999 period.

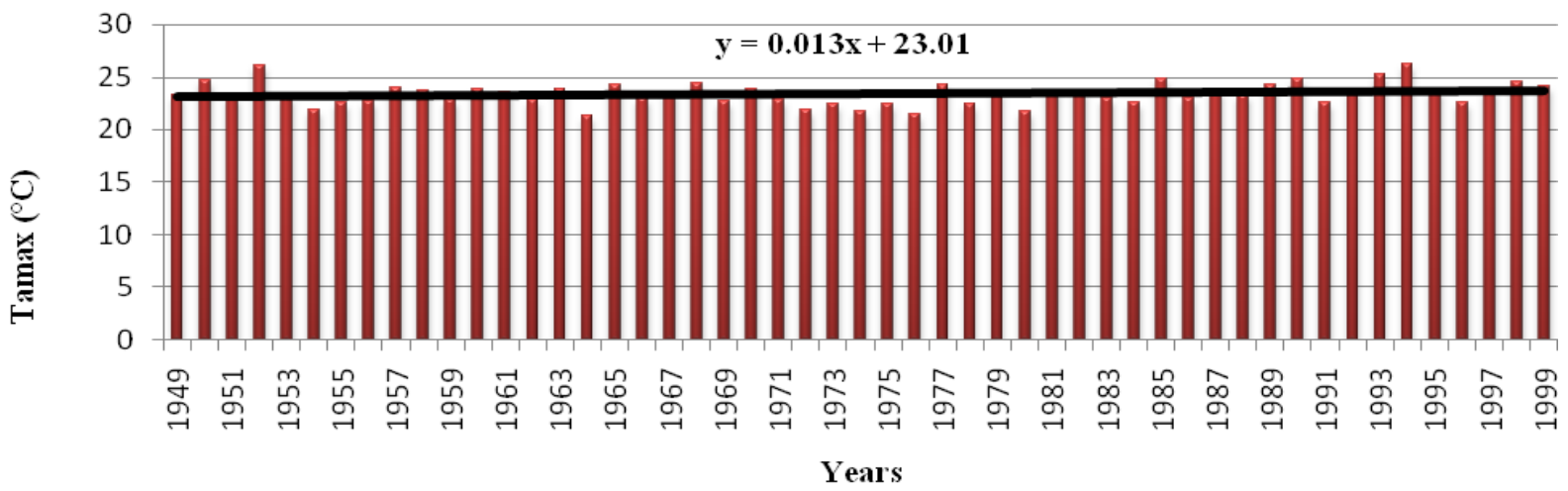

Figure 3. Average maximal annual temperatures, the trend line and the thrend equation for Priština in the 1949 - 1999 period.

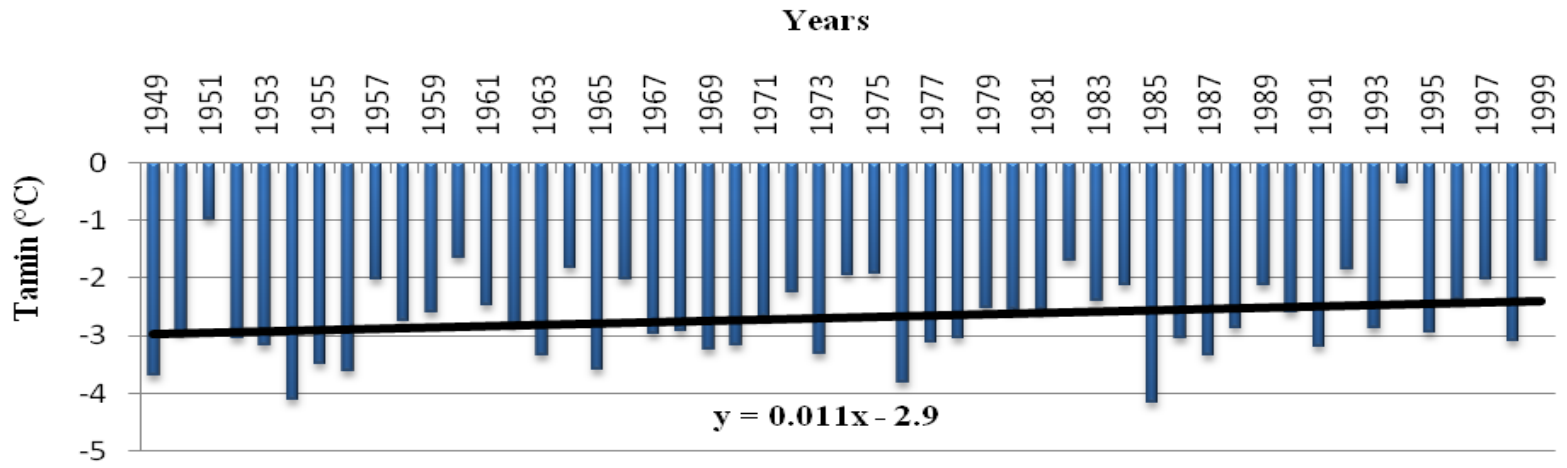

Figure 4. Average minimal annual temperatures, the trend line and the trend equation for Priština in the 1949 - 1999 period. 


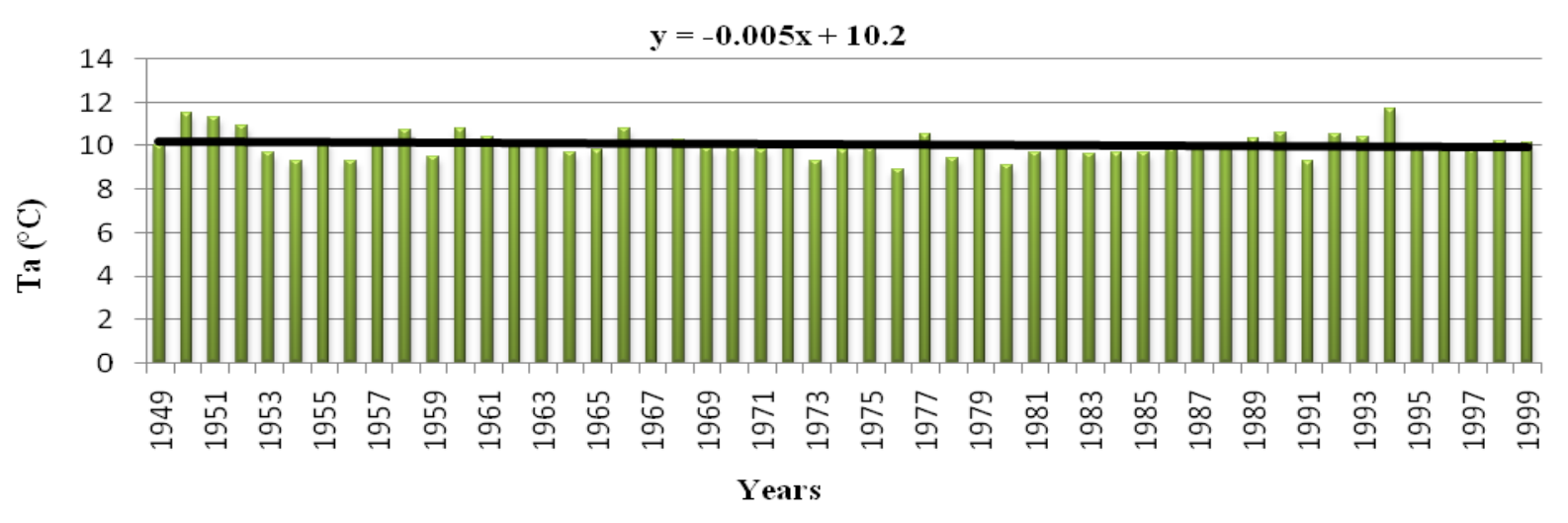

Figure 5. Average annual temperatures, the trend line, the trend equation for Priština in the 1949 - 1999 period.

Negative trend values in the time series can be seen in the Figure 2, as well as in the equation 1-(RRsum) $)_{1,2,3,4}$. The hypothesis test will give us an answer whether this assertion is true or not. The calculated $\mathrm{p}$ value is higher than 0.05 , which means that the null hypothesis should be accepted. The probability for its acceptance is $45.66 \%$. The precipitation difference $\Delta y_{p}$ equals $39.96 \mathrm{~mm}$.

Positive trend values in the time series are seen in the Figure 3, as well as in the equation (2-Tamax) $)_{1,2,3,4}$. The hypothesis test will give us an answer whether this assertion is true or not. The calculated $\mathrm{p}$ value is higher than 0.05 , which means that the null hypothesis should be accepted. The probability for its acceptance is $29.19 \%$. The tempreature difference $\Delta y$ equals $-0.65^{\circ} \mathrm{C}$.

Positive trend values in the time series are seen in the Figure 4, as well as in the equation (3-Tamin) $)_{1,2,3,4}$. The hypothesis test will give us an answer whether this assertion is true or not. The calculated $p$ value is higher than 0.05 , which means that the null hypothesis should be accepted. The probability for its acceptance is $16.24 \%$. The tempreature difference $\Delta y$ equals $-0.58{ }^{\circ} \mathrm{C}$.

Negative trend values in the time series are seen in the Figure 5, as well as in the equation (4-Ta) $)_{1,2,3,4}$. The hypothesis test will give us an answer whether this assertion is true or not. The calculated $\mathrm{p}$ value is higher than 0.05 , which means that the null hypothesis should be accepted. The probability for its acceptance is $47.07 \%$. The tempreature difference $\Delta y$ equals $0.25{ }^{\circ} \mathrm{C}$.

\section{CONCLUSION}

Priština meteorological station was a part of Serbian meteorological system until 1999. It started with data collecting in 1949. Its significance is in its location - near the K\&M province capital. The data used in this study was for the $1949-$ 1999 period. The data processing was organized in two phases. In the first one a random data interpolation took place. In the second phase the XL-stat statistical software was chosen, and using it we came to assertions on data trends for (maximal, minimal, average) temperatures and precipitations. The Mann-
Kendall's trend test was used due to its suitability for meteorological data processing. For the purpose of obtaining long term climate assessments, three statistical trends for two time series were done and a conclusion about Priština trend was drawn. Having in mind results of the MK test, we come to a conclusion that the $H_{0}$ hypothesis should be accepted. The general conclusion is: there is no trend neither in maximal, minimal, average temperatures, nor in average precipitation sums for the 1949 - 1999 period.

\section{ACKNOWLEGMENTS}

The authors sincerely appreciate the efforts of Eugen Ljajko in improving this manuscript.

\section{REFERENCES}

Bačević, R. N., Vukoičić, Z. D., Nikolić, M., Janc, N., Milentijević, N., \& Gavrilov, B. M. 2017. Aridity in Kosovo and Metohija, Serbia. Carpathian Journal of Earth and Environmental Sciences, Vol. 12, No 2, 563-570.

Brázdil, R., Budíková, M., Auer, I., Böhm, R., Cegnar, T., Faško, P., . . . Weber, R.O. 1996. Trends of maximum and minimum daily temperatures in Central and Southeastern Europe. International Journal of Climatology, 16(7), pp. 765782. doi:10.1002/(sici)1097-0088(199607)16:7<765::aidjoc46>3.0.co;2-o

Brunet, M., Jones, P.D., Sigró, J., Saladié, O., Aguilar, E., Moberg, A., . . . López, D. 2007. Temporal and spatial temperature variability and change over Spain during 18502005. Journal of Geophysical Research, 112(12). doi:10.1029/2006jd008249

Brunetti, M., Buffoni, L., Mangianti, F., Maugeri, M., \& Nanni, T. 2004. Temperature, precipitation and extreme events during the last century in Italy. Global and Planetary Change, 40(1-2), pp. 141-149. doi:10.1016/s09218181(03)00104-8

Douglas, E.M., Vogel, R.M., \& Kroll, C.N. 2000. Trends in floods and low flows in the United States: impact of spatial correlation. Journal of Hydrology, 240(1-2), pp. 90-105. doi:10.1016/s0022-1694(00)00336-X

Ducić, V., \& Radovanović, M. 2005. Climate of Republic Serbia.Belgrade: Textbook Institute of Belgrade. in Serbian. 
Feidas, H., Makrogiannis, T., \& Bora-Senta, E. 2004. Trend analysis of air temperature time series in Greece and their relationship with circulation using surface and satellite data: 1955?2001. Theoretical and Applied Climatology, 79(3-4), pp. 185-208. doi:10.1007/s00704-004-0064-5

Gavrilov, M. B., Lazić, L., Pešic, A., Milutinović, M., Marković, D., Stanković, A., \& Gavrilov, M. M. 2010. Influence of Hail Suppression on the Hail Trend in Serbia. Physical Geography, 31(5), pp. 441-454. doi:10.2747/02723646.31.5.441

Gavrilov, M., Lazic, L., Milutinovic, M., \& Gavrilov, M. 2011. Influence of hail suppression on the hail trend in Vojvodina, Serbia. Geographica Pannonica, 15(2), pp. 36-41. doi:10.5937/geopan1102036g

Gavrilov, M.B., Marković, S.B., Zorn, M., Komac, B., Lukić, T., Milošević, M., \& Janićević, S. 2013. Is hail suppression useful in Serbia? - General review and new results. Acta geographica Slovenica, 53(1), pp. 165-179. doi:10.3986/ags53302

Gavrilov, M. B., Marković, S. B., Janc, N., Nikolić, M., Valjarević, A., Komac, B., . . . Bačević, N. 2018. Assessing average annual air temperature trends using the MannKendall test in Kosovo. Acta geographica Slovenica, 58(1). doi:10.3986/ags.1309

Gilbert, R.O. 1987. Statistical Methods for Environmental Pollution Monitoring.New York: Van Nostrand Reinhold.

Hrnjak, I., Lukić, T., Gavrilov, M. B., Marković, S. B., Unkašević, M., \& Tošić, I. 2014. Aridity in Vojvodina, Serbia. Theoretical and Applied Climatology, 115(1-2), pp. 323-332. doi:10.1007/s00704-013-0893-1

-IPCC. 2007. Intergovenmental Panel Climate Change. The physical science basis. In S. Solomon, D. Qin, M. Manning, Z. Chen, M. Marquis, K. B. Averyt, . . . H. L. Miller Eds., Contribution of Working Group I to the Fourth Assessment Report of the Intergovernmental Panel on Climate Change.Cambridge: Cambridge University Press.

Ivanovic, R., Valjarevic, A., Vukoicic, D., \& Radovanovic, D. 2016. Climatic regions of Kosovo and Metohija. The University Thought - Publication in Natural Sciences, 6(1), pp. 49-54. doi:10.5937/univtho6-10409

Kendall, M.G. 1938. A New Measure of Rank Correlation. Biometrika, 30(1/2), p. 81. doi:10.2307/2332226
Kendall, M.G. 1975. Rank correlation methods.London: Charles Griffin.

Klein, T.A.M.G., Wijngaard, J.B., Können, G.P., Böhm, R., Demarée, G., Gocheva, A., \& et al., 2002. Daily dataset of 20th-century surface air temperature and precipitation series for the European Climate Assessment. International Journal of Climatology, 22(12), pp. 1441-1453. doi:10.1002/joc.773

Milentijevic, N., Dragojlovic, J., Cimbaljevic, M., Ristic, D., Kalkan, K., \& Buric, D. 2018. Analysis of equivalent temperature - case of Kragujevac city. Bulletin of the Serbian Geographical Society, 98(1), pp. 61-77. doi:10.2298/gsgd $180225003 \mathrm{~m}$

Tošić, I., Hrnjak, I., Gavrilov, M. B., Unkašević, M., Marković, S. B., \& Lukić, T. 2014. Annual and seasonal variability of precipitation in Vojvodina, Serbia. Theoretical and Applied Climatology, 117(1-2), pp. 331-341. doi:10.1007/s00704013-1007-9

Unkašević, M., \& Tošić, I. 2009. Changes in extreme daily winter and summer temperatures in Belgrade. Theoretical and Applied Climatology, 95(1-2), pp. 27-38. doi:10.1007/s00704-007-0364-7

Unkašević, M., \& Tošić, I. 2011. The maximum temperatures and heat waves in Serbia during the summer of 2007. Climatic Change, 108(1-2), pp. 207-223. doi:10.1007/s10584-010-0006-4

Unkašević, M., \& Tošić, I. 2013. Trends in temperature indices over Serbia: relationships to large-scale circulation patterns. International Journal of Climatology, 33(15), pp. 3152-3161. doi:10.1002/joc.3652

Valjarević, A., Djekić, T., Stevanović, V., Ivanović, R., \& Jandziković, B. 2018. GIS numerical and remote sensing analyses of forest changes in the Toplica region for the period of 1953-2013. Applied Geography, 92, pp. 131-139. doi:10.1016/j.apgeog.2018.01.016

Vukoičić, D., Milosavljević, S., Penjišević, I., Bačević, N., Nikolić, M., Ivanović, R., \& Jandžiković, B. 2018. Spatial analysis of air temperature and its impact on the sustainable development of mountain tourism in Central and Western Serbia. Időjárás Quarterly Journal of the Hungarian Meteorological Service, 122(3), pp. 259-283. doi:10.28974/idojaras.2018.3.3 